\title{
Correction: Cloning and analysis of a bifunctional methyltransferase/restriction endonuclease TspGWI, the prototype of a Thermus sp. enzyme family
}

\author{
Agnieszka Zylicz-Stachula ${ }^{1}$, Janusz M Bujnicki ${ }^{2}$ and Piotr M Skowron ${ }^{1 *}$
}

\section{Correction}

The TspGWI restriction endonuclease, which originates from thermophilic Thermus sp. GW, was cloned previously [1] in Escherichia coli (E. coli) using a method employing aa sequencing of proteolytic fragments $\mathrm{N}$-termini, followed by a combination of sequencing of degenerated, inverse and standard PCR products and clones containing the tspGWIRM gene. A combination of these methods yielded a sequence of $3688 \mathrm{bp}$, comprising an entire TspGWI Open Reading Frame (ORF: 3291 bp) and flanking sequences [GenBank: EF095488, ABO26710]. However, more recent resequencing of the tspGWIRM gene with the use of genomic Thermus sp. GW DNA as a template in PCR, obtained with primers external to ORF, has revealed a sequencing error. This resulted in a frameshift of 233 aa, starting at aa 740 and returning to the original ORF at aa 973. The frameshift was located within the 3 '-terminal portion of the gene, coding for a Target Recognition Domain (TRD). The nt sequence of the tspGWIRM gene was corrected at $2217 \mathrm{bp}$ (C insertion) and further downstream at $2915 \mathrm{nt}$ (C deletion), restoring the ORF (Additional file one (Additional file 1 here) and Figure five (Figure 1 here) corrected).
New figures have been prepared using the corrected DNA and aa sequences (Figure five (Figure 1 here) and Additional file one (Additional file 1 here)). Data concerning corrected nt and aa TspGWI sequence have been deposited in GenBank [GenBank: KJ730526].

The correction was located within a variable TRD segment, thus the conclusions of the bioinformatics sequence analysis must be slightly modified compared to our originally published results [1]. The corrected sequence of TspGWI shows similarity to the TaqII sequence and residues 660-960 in TspGWI that were originally (in the previous version) predicted to be intrinsically disordered, were predicted to be precisely ordered in the corrected version of the sequence (data not shown).

The DNA sequence and the predicted amino acid sequence of the $120.2 \mathrm{kDa}$ TspGWI protein is indicated in capital letters. DNA sequences of flanking regions are indicated in italics. The ATG start codon and TGA stop codon are emboldened and underlined. Potential TspGWI Ribosome Binding Sites (RBS) are emboldened, underlined italics.

* Correspondence: piotr.skowron@ug.edu.pl

'Division of Molecular Biotechnology, Department of Chemistry, Institute for Environmental and Human Health Protection, University of Gdansk, Wita Stwosza 63, 80-308 Gdansk, Poland

Full list of author information is available at the end of the article 


\section{Additional file}
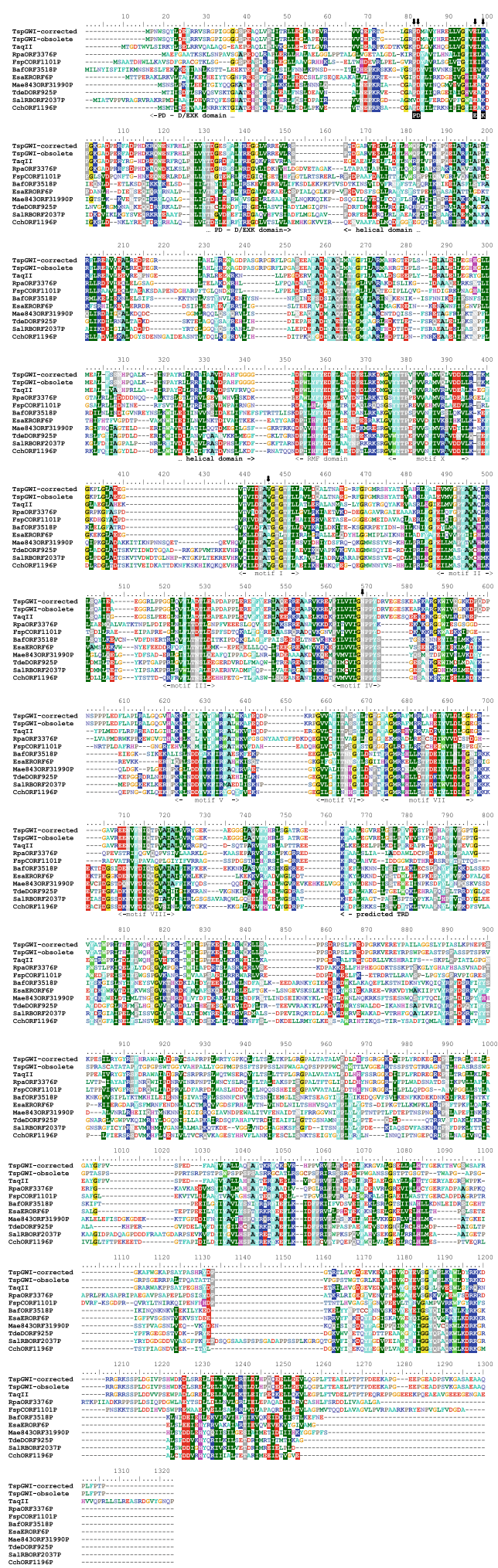

Figure 1 Sequence alignment between TspGWI and its close homologues in REBASE.
Additional file 1: tspGWIRM gene and its flanking regions.

\section{Acknowledgements}

This work was supported by DS/530-8640-D509-14 (PMS, AZS), Gdansk University, Chemistry Department DS fund. JMB was supported by the statutory funds of the IIMCB and the UAM.

\section{Author details}

'Division of Molecular Biotechnology, Department of Chemistry, Institute for Environmental and Human Health Protection, University of Gdansk, Wita Stwosza 63, 80-308 Gdansk, Poland. 'Laboratory of Bioinformatics and Protein Engineering, International Institute of Molecular and Cell Biology in Warsaw, Ks. Trojdena 4, 02-109 Warsaw, and Institute of Molecular Biology and Biotechnology, Faculty of Biology, Adam Mickiewicz University,

Umultowska 69, Poznan, Poland.

Received: 18 June 2014 Accepted: 25 June 2014

Published: 5 August 2014

\section{Reference}

1. Żylicz-Stachula A, Bujnicki JM, Skowron PM: Cloning and analysis of bifunctional DNA methyltransferase/nuclease TspGWI, the prototype of a Thermus sp. family. BMC Mol Biol 2009, 10:52

doi:10.1186/1471-2199-15-16

Cite this article as: Zylicz-Stachula et al:: Correction: Cloning and analysis of a bifunctional methyltransferase/restriction endonuclease TspGWl, the prototype of a Thermus sp. enzyme family. BMC Molecular Biology 2014 15:16.

\section{Submit your next manuscript to BioMed Central and take full advantage of:}

- Convenient online submission

- Thorough peer review

- No space constraints or color figure charges

- Immediate publication on acceptance

- Inclusion in PubMed, CAS, Scopus and Google Scholar

- Research which is freely available for redistribution 